\title{
Formasi Tinggalan Budaya Permukaan Situs Medowo
}

\section{Bugie M.H. Kusumohartono}

Keywords: ancient; indonesia; artefacts; hinduism; east java; quantitative; survey; archaeology

\section{How to Cite:}

Kusumohartono, B. M. (1990). Formasi Tinggalan Budaya Permukaan Situs Medowo. Berkala Arkeologi, 11(1), 48-67. https:/ / doi.org/10.30883/jba.v11i1.550

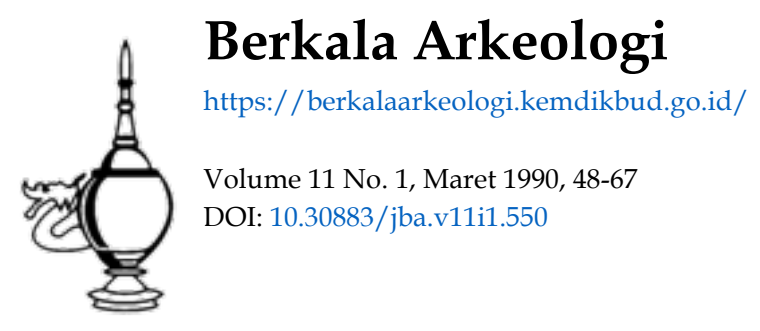




\section{FORMASI TINGGALAN BUDAYA PERMUKAAN SITUS \\ MEDOWO}

\section{Oleh: \\ Bugie Kusumohartono}

\section{Pendahuluan}

Situs Medowo terletak di Delta Brantas, kurang le-bih lima kilometer sebelah timur percabangan Sungai Brantas menjadiSungai Mas (Surabaya) dan Sungai Porong. Mayoritas dari area situs secara administratif termasuk dalam wilayah Desa Gampingrowo, Kecamatan Tarik, Ka-bupaten Sidoarjo, Jawa Timur. Pada peta topografi, si-tus Medowo berada antara 50 41'3" 5041'19" Bujur Ti-mur dan 7026'15" - 7027'18" Lintang Selatan, meredian Jakarta (lampiran peta).

Potensi situs Medowo dikenali berdasarkan penınjauan arkeologik oleh Balai Arkeologi Yogyakarta pada bulan Agustus 1986. Di permukaan situs dijumpai berbagai tinggalan arkeologik, di antaranya tembikar, bata, terakota, keramik asing, lumpang batu, dan batu calon prasasti andesitik, yang sepintas memperlihatkan corak bu-daya Indonesia kuna (klasik). Berbagai tinggalan tersebut tersebar di area yang relatif luas dan merupakan petun-juk bahwa situs Medowo pernah berfungsi sebagai lokasi suatu pusat kegiatan pada periode Indonesia kuna.

Kenyataan tersebut merupakan hal yang menarik, khususnya bagi Balai Arkeologi Yogyakarta, karena situs-situs non-upacara bercorak klasik relatif masih kurang mendapatkan perhatian. Terlebih lagi situs Medowo ber-ada pada suatu kawasan khas -- yakni Tarik -- sebuah toponim yang mengacu pada toponim kuna ... alasing wong trik. Sebagaimana diketahui, toponim kuna terse-but pernah disuratkan dalam sumber sejarah, sehubungan dengan peristiwa runtuhnya kekuasaan politik Singhasari dan berdirinya Majapahit (akhir abad ke-13). 
Salah satu studi awal yang diselenggarakan di situs tersebut adalah studi penjajagan (exploratory research), yang bertujuan untuk mengidentifikasikan batas areal situsnya. Studi penjajagan tersebut diwujudkan dalam bentuk survei permukaan secara terkendali pada seluruh permukaan situs. Survei tersebut terlaksana pada penelitian Situs Medowo tahap I - 1987 dan tahap III - 1990 (perhatikan Mueller 1975: 34-5).

Pada tulisan ini akan dicoba untuk memperoleh hasil sampingan yang dapat dipetik dari studi penjajagan tersebut yaitu pengetahuan tentang pola agihan (distribution), kekerapan (frequency), dan kerapatan (density) tinggalan arkeologik di permukaan situs. Dengan hasil-hasil itu maka penelitian lanjutan (multi stage research) berupa studi-studi deskriptif dan eksplanatif di Situs Medowo dapat diselenggarakan secara lebih efisien (perhatikan Redman 1973).

\section{Lingkungan Fisik Situs Medowo}

Sebagaimana disinggung di atas, situs Medowo terletak di Delta Brantas, yang secara genetik daerah ini merupakan satuan bentuklahan dataran aluvial. Sebagai bagian dari Delta Brantas, areal situs Medowo terbentuk karena pengendapan material aluvium dari Sungai Brantas dalam jangka yang lama. Topografi relatif berelief datar, sedang mikrorelief daerah ini memperlihatkan kemiringan lereng $0^{\circ}-2^{\circ}$ ke arah timur.

Proporsi terbesar terutama bagian barat situs Medowo merupakan suatu cekungan luas, sedangkan sisanya yaitu bagian timur situs Medowo merupakan punggungan sempit yang pada saat ini dimanfaatkan sebagai areal hunian dusun Medowo. Karena bagian barat topografinya cekung maka limpahan banjir sungai pernah menggenangi areal ini sehingga tercipta rawa (backswamp).

Sungai kuna yang melimpahkan airnya ke rawa tersebut dewasa ini sudah tidak dijumpai lagi. Namun ke- 
beradaarinya masih tertinggal pada toponim-toponim pemukiman yang berjajar di sebelah selatan cekungan, kurang lebih satu kilometer di selatan dusun Medowo. Toponim-toponim tersebut antara lain adalah Kedungklinter, Kedungploso, dan Kedungbocok. Sementara itu bekas rawa yang disebut di atas masih bisa ditelusuri keberadaannya pada toponim Gampingrowo (Madura, tepi rawa), yaitu kelompok hunian tepat di tepi barat laut cekungan tersebut. Pada saat ini areal cekungan tersebut merupakan kawasan persawahan yang cukup subur.

Di kawasan ini air tanah dijumpai pada kedalaman 2-3 meter di musim kemarau, dalam endapan batuan aluvium yang terdiri dari pasir; kerikil; debu; dan mayoritas lempung.

Sementara itu tepat di selatan pemukiman Medowo terdapat sebuah sungai kecil (Patusan) yang airnya mengalir ke timur. Lebar sungai pada tepinya sekitar empat meter. Di dasar sungai tersebut, terutama di bagian sungai yang mengalir di sebelah barat-daya dusun Medowo, terdapat hamparan fragmen artefak tembikar. Semakin ke barat dan mendekati kompleks makam Klinter, intensitas fragmen tembikar tersebut semakin tinggi.

\section{Penjaringan Data}

Penelitian penjajagan berupa survei muka tanah pada tahun 1987 dan 1990 di situs Medowo meliputi satuan-satuan tata guna lahan berupa hunian, pemakaman, dan sawah/tegalan. Pelaksanaan survei tidak dibatasi luasnya karena area yang potensial mengandung tinggalan arkeologik belum diketahui batasnya. Namun berdasarkan peninjauan pada tahun 1986 diketahui bahwa area potensial tersebut memanjang mulai dari Dusun Medowo di timur sampai jauh ke arah barat.

Dalam rangka efisiensi, rancangan survei permukaannya menerapkan sistem pencuplikan terkendali, dengan asumsi bahwa formasi tinggalan budaya di permukaan 
situs tersebut masih meyakinkan. Adanya transformasi membentuk konteks arkeologik (archaeological context) memang dimungkinkan, namun diduga itu pun sebatas transformasi vertikal berupa terangkat dan terkuburnya tinggalan arkeologik karena aktivitas manusia pada saat ini. Walaupun nampaknya ada perbedaan intensitas transformasi (tafonomi) antara yang berlangsung di kawasan hunian dan pertanian, sejauh, ini belum diketahui dengan pasti apakah perbedaan tersebut memang meyakinkan (significance) ataukah dapat diabaikan saja (perhatikan Reid, Schiffer, dan Neff 1975).

Pada dasarnya survei tahun 1987 dan 1990 tersebut menerapkan modifikasi sekaligus integrasi teknik pencuplikan geometrik secara sistematik (systematic, geometric sampling) dan pencuplikan jalur (transect sampling). Sesuai dengan tujuan penelitian penjajagan tahun 1987 dan 1990 tersebut, strategi pencuplikan ini dipilih karena kemampuan-kemampuan khususnya. Pencuplikan geometrik-sistematik

... is especially valuable in discovering patterns of artifact distribution across a geographic area such as an archaeological site (Redman 1974: 12).

Sementara itu pencuplikan jalur dimanfaatkan pula karena

... especially useful for observing gradients of change over an area and for delimiting boundaries of a phenomenon. There are several archaeological situations where samples arranged along linear traverses, or transects, can be very informative (Redman 1974: 16).

Jalur-jalur survei disusun membujur utara-selatan, seluas mungkin sehingga mampu meliput seluruh area potensial. Jalur-jalur tersebut memotong sumbu $x$, yaitu suatu garis maya barat-timur yang memotong di tengah dusun $\mathrm{Me}-$ dowo tepat pada jalan utama lingkungan hunian. 
Titik pengukuran awal (primary datum point) berada di depan rumah Bapak Kasmin (base camp Tim Peneliti) dengarı elevasi 15.30 meter dpl. Titik pengukuran awal tersebut merupakan perpotongan antara sumbu $X$ dan sumbu $Y$. Sumbu $Y$ adalah garis maya yang membujur utara-selatan dan membelah bidang survey menjadi dua, yaitu bagian barat dan bagian timur.

Survei dilakukan mengikuti jalur-jalur garis (1ine transects) yang satu sama lain berinterval 25 meter. Titik-titik pencuplikan atau disingkat TP (sampling points) dalam satu jalur garis juga berinterval 25 meter. Pencuplikan baku (standard sampling) dilaksanakan pada setiap TP, seluas 4 meter persegi di permukaan tanah. Lokasi TP dimungkinkan untuk tidak sepenuhnya konsisten dengan rencana karena adanya kendala-kendala, misalnya tepat di tengah selokan atau bertepatan di tengah rumah tinggal.

Setiap jalur garis di sebelah barat titik pengukuran awal diberi kode angka Arab, mulai 0 di sumbu $Y$ dan seterusnya, sedang untuk jalur garis di sebelah timur sumbu $Y$ diberi kode angka Romawi. TP di sebelah utara sumbu $X$ diberi kode huruf tunggal $(A, B, C$, dan seterusnya), sedang bagi yang di sebelah selatan diberi kode huruf ganda (AA, BB, CC, dan seterusnya).

Dalam kenyataannya jalur survei yang menghasilkan data arkeologik berjumlah 24 buah, yang meliputi jalurjalur $20,19,18,17,16,15,14,12,11,10,9,8,7,6$, $5,4,3,2,1,0$, I, II, III, dan IV. Sementara itu keseluruhan TP yang mengandung tinggalan arkeologik berjumlah 110 buah.

Penetapan agihan, kekerapan, dan kerapatan tinggalan budaya permukaan diselenggarakan melalui kuantifikasi data arkeologik dengan prosedur perhitungan statistik deskriptif. Melalui cara ini maka informasi yang berupa fakta-fakta khusus yang memperlihatkan adanya pola-pola tertentu pada data arkeologik dapat dipahami dengan lebih gamblang (Clark 1982: 220). 


\section{Paparan Hasil Penjaringan Data}

Secara umum jenis tinggalan arkeologik yang dijaring dalam survei-survei tersebut meliputi berbagai fragmen tembikar, keramik asing, bata, genting, bandul jala, mata uang, alat logam, tulang, dan alat batu. Selain bandul jala, alat batu, alat logam, mata uang, dan tulang, maka empat jenis data arkeologik yang lain dijumpai relatif merata pada jalur-jalur survei. Kehadiran empat jenis tinggalan arkeologik tersebut -- tembikar, keramik asing, genting, dan bata -- akan dianalisis lebih lanjut di bawah.

Memperhatikan agihan tinggalan arkeologik pada jalur-jalur survei, pertama-tama dapat dilihat batas lahan yang mengandung tinggalan budaya masa lampau. Lahan yang potensial bagi penelitian arkeologik tersebut meliputi seluruh Dusun Medowo sampai ke sebelah utara dan selatannya. Area tersebut memanjang barat-timur dengan panjang sekitar 1400 meter dan lebar sekitar 300 meter. Batas sebelah timur area tersebut adalah jalan desa yang menghubungkan Desa Balongbendo dan Desa Kedungbocok. Batas sebelah baratnya adalah bagian barat dari Makam Klinter. Area yang potensial inilah yang disebut sebagai Situs Medowo.

Berbeda dengan sebagian yang sisi timur, bagian sisi barat Situs Medowo merupakan area yang sempit memanjang barat-timur dan terletak di sebelah selatan garis maya sumbu Y. Secara administratif, bagian selatan Situs Medowo bukan lagi merupakan bagian dari Desa Gampingrowo, namun termasuk dalam lingkup Desa Kedungbocok.

Dari 25 jalur yang mengandung tinggalan arkeologik, beberapa jalur survei memperlihatkan intensitas temuan yang lebih tinggi dari pada jalur survei yang lain. Di bawah ini diperlihatkan agihan dari kekerapan tinggalan arkeologik pada jalur-jalur survei (Tabel 1). 


\section{Tabel 1}

\begin{tabular}{|c|c|c|c|c|c|}
\hline \multirow{2}{*}{ Jalur survei } & \multicolumn{5}{|c|}{ Tinggalan arkeologik (gram/4 meter persegi) } \\
\hline & Temb. & K.A. & Gtg. & Bata & Lain-lain \\
\hline 20 & 2 & - & - & 1500 & - \\
\hline 19 & 138 & 5 & - & 4486 & - \\
\hline 18 & 956 & - & 49 & 10600 & - \\
\hline 17 & 67 & 5 & - & 30000 & 36 [Mt.ug] \\
\hline 16 & 1503 & 70 & 65 & 25550 & - \\
\hline 15 & 81 & - & - & 130 & - \\
\hline 14 & - & 2 & 56 & 700 & - \\
\hline 13 & - & - & - & - & - \\
\hline 12 & 287 & 4 & - & 6750 & - \\
\hline 11 & 389 & 2 & 37 & 3940 & - \\
\hline 10 & 754 & 48 & - & 16700 & - \\
\hline 9 & 356 & 110 & 19 & 2384 & - \\
\hline 8 & 267 & 3 & 274 & 6200 & - \\
\hline 7 & 137 & - & - & 1525 & $126[\mathrm{Tlg}]$ \\
\hline 6 & 142 & 2 & 37 & 4200 & - \\
\hline 5 & 2750 & 54.5 & 902 & 28976 & 4 [Mt.ug] \\
\hline 4 & 1458 & 40.5 & 171 & 36400 & - \\
\hline 3 & 745 & 19 & 144 & 16700 & - \\
\hline 2 & 370 & 10 & 881 & 260 & 50 [Bd.jl] \\
\hline 1 & 331 & - & 797 & 1742 & - \\
\hline 0 & 55 & - & 24 & 650 & - \\
\hline I & 1249 & 75 & 3166 & 3250 & $20[\mathrm{Lg}], 26[\mathrm{Bt}]$ \\
\hline II & 630 & 45 & 2240 & 2800 & - \\
\hline III & - & - & 133 & 190 & $190[\mathrm{Bt}]$ \\
\hline IV & 6 & - & - & 1850 & - \\
\hline Tot a 1 & 12673 & 495 & 8995 & 207483 & $\begin{array}{l}50 \text { [Bd.jl], } 216 \\
\text { [Bt], 20 [Lg], } \\
40[\mathrm{Mt} . u g], 126 \\
\text { [Tlg] }\end{array}$ \\
\hline
\end{tabular}

Keterangan :

Temb.: Tembikar, K.A : Keramik Asing, Gtg.: Genting, Bd.jl. : Bandul jala, Bt. : Batu, Lg.: Logam, Mt.ug. : Mata uang, Tlg: : Tulang. 
Apabila diurutkan berdasarkan peringkat lima jalur survei yang tertinggi intensitasnya, maka temuan artefak tembikar yang tertinggi terdapat pada jalur 5, kemudian berturut-turut jalur 16, 4, I, dan 18. Intensitas keramik asing berturut-turut dari yang tertinggi adalah jalur 9, I, 16, S, dan 10. Peringkat temuan genting berdasarkan intensitasnya berturut-turut adalah jalur I, II, 5, 2, dan 1. Sementara itu peringkat intensitas temuan bata berturut-turut adalah jalur $4,17,5,16$, dan 10/3.

Dari uraian di atas secara sekilas nampak bahwa beberapa jalur survei lebih potensial tinggalan arkeologiknya ketimbang jalur yang lain. Jalur-jalur potensial tersebut adalah jalur 16 (bersama 17 dan 18), jalur 1C (bersama 9), jalur 5 dan 4 (bersama 3, 2, dan 1), serta jalur I (bersama II). Gambaran yang lebih jelas dapat dilihat pada kurve di bawah ini (gambar 1).

\section{Gambar 1}

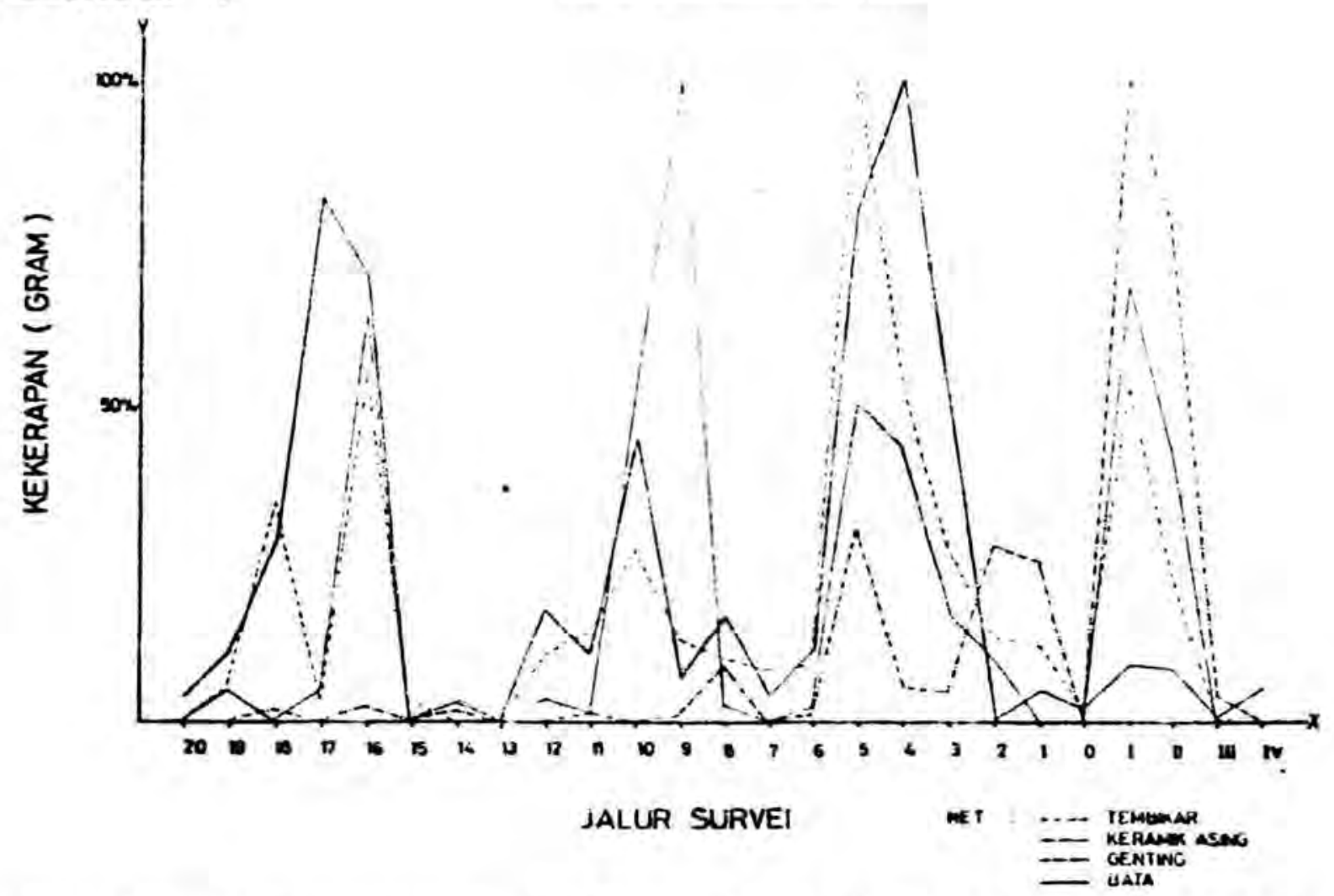

Grafik Menunjukkan Agihan Dari Prosentase Kekerapan Empat Jenis Artefak Pokok Pada Jalur-jalur Survei 
Gambar di atas memperkuat identifikasi mengenai empat kelompok jalur survei yang potensial di situs ini. Pada dua kelompok jaiur potensial sebelah barat terlihat adanya korelasi positif antara tiga jenis artefak, yaitu tembikar, keramik asing, dan bata, dengan catatan populasi keramik sangat tinggi di jalur 9. Di lain pihak korelasi positif dari empat jenis artefak tersebut terlihat pada kelompok jalur 5 dan 4. Sebaliknya, pada kelompok jalur potensial paling timur korelasi positif muncul pada tiga jenis artefak yang berbeda, yaitu tembikar, keramik asing, dan genting.

Dari fenomena di atas terlihat adanya korelasi positif yang "selalu" diperlihatkan oleh artefak tembikar dan keramik. Sementara itu terlihat pula kecenderungan adanya korelasi negatif antara dua jenis artefak yang lain -- yang sebenarnya bersama-sama merupakan elemen bangunan - yaitu fragmen bata dan fragmen genting.

Berdasar pada asumsi bahwa keberadaan artefak khususnya bata dan genting -- sangat terpengaruh oleh aktivitas pendirian bangunan masa kini, maka diestimasikan bahwa kedua jenis artefak tersebut akan muncul bersama-sama dalam intensitas yang tinggi di kawasan hunian Medowo. Sebaliknya, keberadaan kedua jenis artefak tersebut akan rendah intensitasnya di kawasan non hunian, dalam hal ini kawasan pertanian. Namun fakta empirik memperlihatkan kenyataan yang sebaliknya, yaitu terdapat akumulasi bata [hampir tanpa genting] dalam jumlah besar di areal persawahan/makam Klinter, dan sebaliknya terdapat akumulasi genting [hampir tanpa bata] dalam jumlah besar di areal sudut tenggara Dusun Medowo.

Berdasarkan fenomena tersebut dapat digambarkan adanya dua fakta khusus. Pertama, tidak ada korelasi antara jenis kegiatan manusia sekarang -- baik hunian maupun pertanian - dengan formasi jenis-jenis artefak di permukaan situs tersebut. Kedua, terdapat pengkhu- 
susan dalam agihan artefak di Situs Medowo, yang kemungkinan disebabkan oleh ragam fungsi tata ruang $\mathrm{Me}-$ dowo kuna.

Berdasarkan gambaran di atas telah dapat diketahui pola agihan dan kekerapan tinggalan arkeologik Situs Medowo pada jalur-jalur survei permukaan. Selanjutnya akan dicoba pula untuk memahami pola kerapatan tinggalan arkeologik tersebut guna memperoleh gambaran tentang titik-titik pencuplikan [TP] yang potensial.

Telah disampaikan di atas bahwa TP yang mengandung tinggalan arkeologik berjumlah 110 buah. Namun demikian tidak semua TP mengandung seluruh jenis tinggalan arkeologik yang dijumpai di situs Medowo. Di bawah iniakan diperlihatkan kehadiran tinggalan arkeologik. pada 110 TP survei permukaan Situs Medowo [Tabel 2]. Setelah agihan tinggalan arkeologik pada seluruh TP

\section{Tabel 2}

\begin{tabular}{l|c|c|cc}
\multirow{2}{*}{ Tinggalan Arkeologik } & \multicolumn{3}{|c}{ Kekerapan TP [n = 110] } \\
\cline { 2 - 4 } & Hadir & Kosong & Prosentase \\
\hline Tembikar & 81 & 29 & 74 & $\%$ \\
Keramik Asing & 22 & 58 & 20 & $\%$ \\
Genting & 39 & 71 & $35 \%$ \\
B a t a & 77 & 33 & $70 \%$ \\
Mata Uang & 2 & 108 & $1.82 \%$ \\
B a t u & 2 & 108 & $1.82 \%$ \\
Bandul Jala & 1 & 109 & $0.91 \%$ \\
Tulang & 1 & 109 & $0.91 \%$
\end{tabular}

survei diketahui, maka perlu pula untuk diketahui pola kerapatan tinggalan-tinggalan arkeologik -- terutama artefak tembikar, keramik asing, genting, dan bata -. di Situs Medowo ini.

Untuk memperoleh gambaran tentang pola kerapatan empat jenis artefak tersebut pada semua TP survei maka pertama-tama disusun terlebih dahulu tabel agihan kekerapan (frequency distributions). Dalam memanfaatkan Berkala Arkeologi XI (1) 
rumus baku statistik untuk menetapkan banyak kelas dari suatu tabel agihan kekerapan $(1+3.3 \log n)$ ] [Pasaribu 1965: 35], hasil perhitungannya memperlihatkan jumlah kelas yang tidak seragam antara satu jenis artefak dengan jenis artefak yang lain. Jumlah kelas yang seharusnya berlaku bagi tabel agihan kekerapan temuan tembikar adalah enam kelas, kemudian masing-masing untuk temuan keramik asing dan genting adalah lima kelas, dan untuk temuan bata adalah tujuh kelas. Untuk mengetahui pola kerapatan empat artefak tersebut secara teintegrasi, maka jumlah kelas untuk masing-masing jenis artefak diseragamkan sebanyak lima kelas. Sementara itu kriteria untuk kerapatan artefak, secara khusus diindikasikan oleh ințerval kelas.

Nama kelas dan interval kelas untuk masing-masing artefak tersebut adalah sebagai berikut di bawah ini (tabel 3).

\section{Tabel 3}

Tembikar [gram/4 m2]

Keramik Asing [gram/4 m2]

\begin{tabular}{|c|c|c|c|c|}
\hline $\begin{array}{l}\text { Nama } \\
\text { Kelas }\end{array}$ & Interval Kelas & & $\begin{array}{l}\text { Nama } \\
\text { Kelas }\end{array}$ & Interval Kelas \\
\hline 1 & $1 \ldots 205$ & 1 & 1 & $1-23$ \\
\hline 2 & $206-410$ & & 2 & $24-46$ \\
\hline 3 & $411-615$ & & 3 & $47-69$ \\
\hline 4 & $616-820$ & & 4 & $70-92$ \\
\hline 5 & $821-1025$ & & 5 & $93-115$ \\
\hline
\end{tabular}

Genting [gram/4 m2]

\begin{tabular}{|c|c|c|c|}
\hline $\begin{array}{l}\text { Nama } \\
\text { Kelas }\end{array}$ & Interval Kelas & $\begin{array}{l}\text { Nama } \\
\text { Kelas }\end{array}$ & Interval Kelas \\
\hline $\begin{array}{l}1 \\
2 \\
3 \\
4 \\
5\end{array}$ & $\begin{array}{r}1-269 \\
270-538 \\
539-807 \\
808-1076 \\
1077-1345\end{array}$ & $\begin{array}{l}1 \\
2 \\
3 \\
4 \\
5\end{array}$ & $\begin{array}{r}28-3022 \\
3023-6017 \\
6018-9012 \\
9013-12007 \\
12008-15002\end{array}$ \\
\hline
\end{tabular}


Sementara itu populasi TP pada masing-masing kelas adalah sebagai berikut [tabel 4]. Melalui klasifikasi keTabel 4

\begin{tabular}{|c|c|c|c|c|}
\hline \multirow[b]{2}{*}{ Nama Kelas } & \multicolumn{2}{|r|}{ Populasi } & \multicolumn{2}{|l|}{$T P$} \\
\hline & Tembikar & Keramik Asing & Genting & Bata \\
\hline $\begin{array}{ll}\text { Kelas } & 0 \\
\text { Kelas } & 1 \\
\text { Kelas } & 2 \\
\text { Kelas } & 3 \\
\text { Kelas } & 4 \\
\text { Kelas } & 5\end{array}$ & $\begin{array}{r}28 \\
64 \\
9 \\
5 \\
0 \\
4\end{array}$ & $\begin{array}{r}87 \\
16 \\
4 \\
2 \\
0 \\
1\end{array}$ & $\begin{array}{r}70 \\
29 \\
7 \\
1 \\
1 \\
2\end{array}$ & $\begin{array}{r}32 \\
60 \\
7 \\
4 \\
2 \\
5\end{array}$ \\
\hline Tot a 1 & 110 & 110 & 110 & 110 \\
\hline
\end{tabular}

rapatan tersebut dapat pula digambarkan dengan lebih mudah pola kehadiran empat jenis artefak pokok pada 110 TP yang dihasilkan dalam survei ini [gambar 2].

\section{Gambar 2}

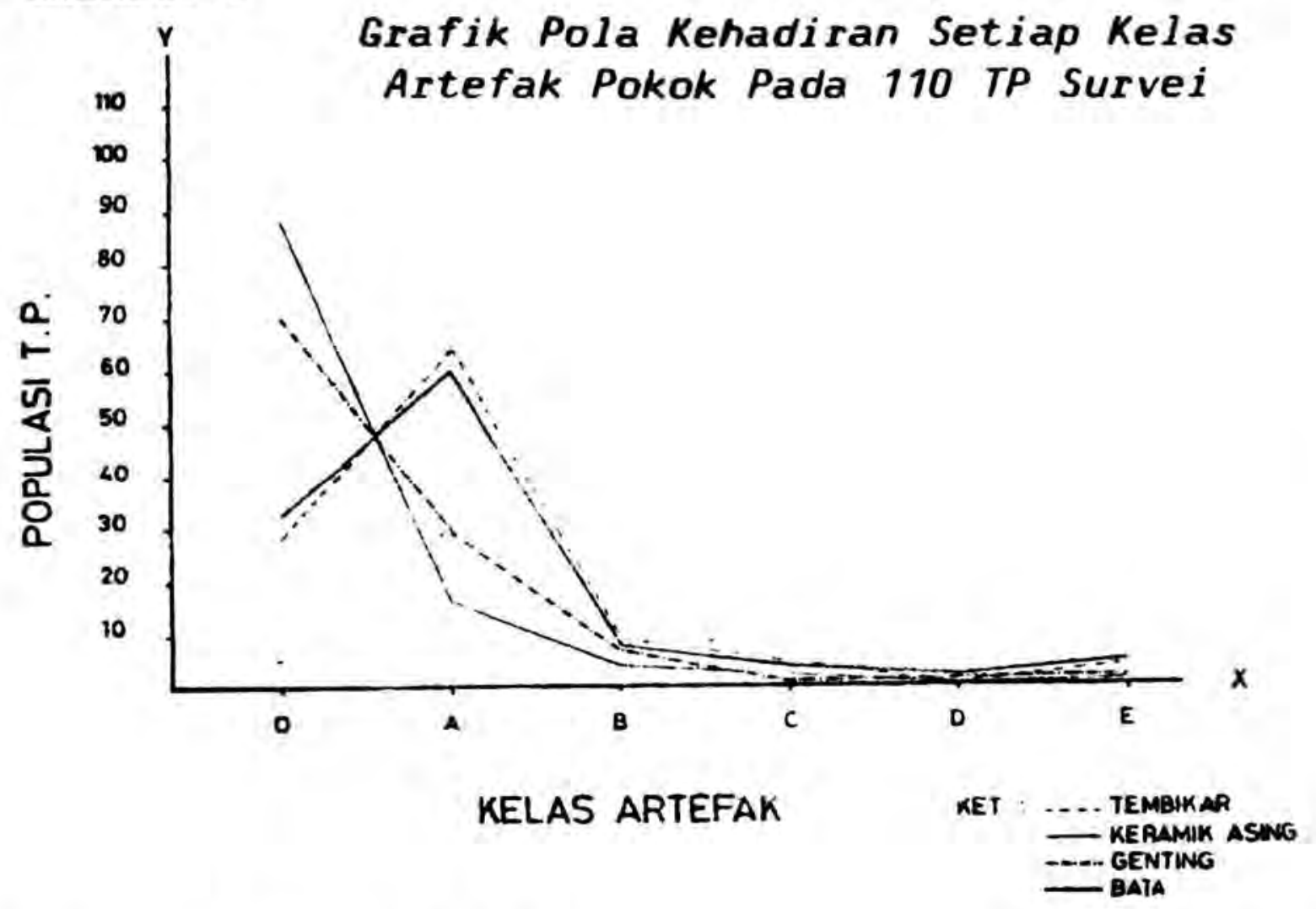


Gambar 2 di atas memperlihatkan bahwa sebagian TP memiliki kerapatan artefak tembikar dan bata yang relatif rendah (kelas 1 dan 2), dan bahkan sebagian yang lain sama sekali tidak memiliki kandungan artefak yang lain yaitu keramik asing dan genting. Di lain pihak hanya sebagian kecil di antara TP hasil survei tersebut yang memiliki kerapatan tinggi pada artefak tembikar, keramik asing, genting, dan juga bata [kelas 4 dan 5]. Mengenai apakah kehadiran jenis-jenis artefak tersebut memperlihatkan suatu pola tertentu yang saling berhubungan satu sama lain, akan dapat dipahami dengan lebih jelas pada kurve berikut ini (gambar 3 ).

\section{Gambar 3}

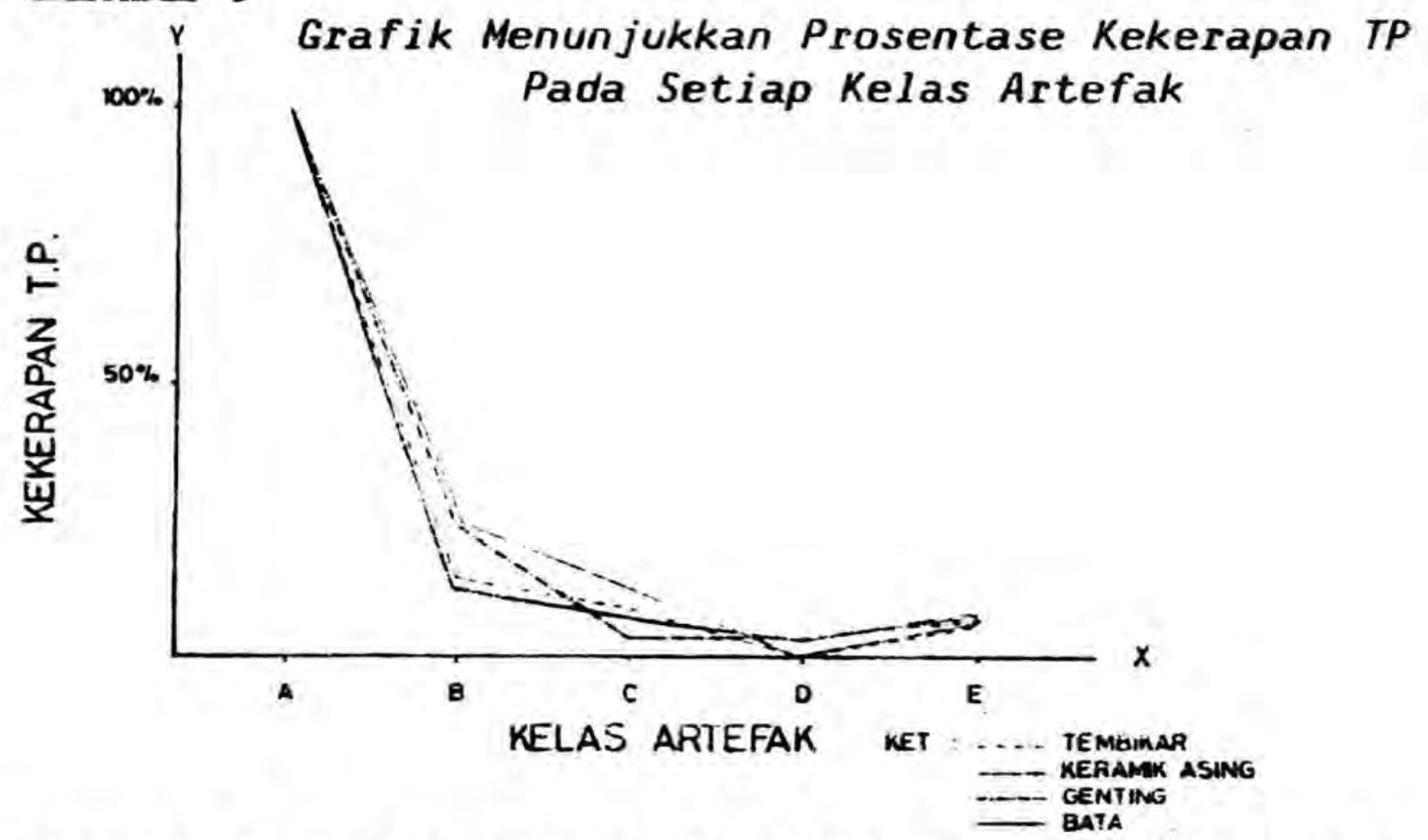

Gambar 3 di atas menunjukkan bahwa perbandingan prosentase kekerapan TP pada seluruh artefak pokok antara kelas 2, 3, 4, dan 5 ternyata relatif konsisten (ajeg), yaitu bergerak di sepanjang garis kekerapan $10 \%$. Kesenjangan yang mencolok terlihat pada perbedaan prosentase kekerapan dari kelas-kelas tersebut dengan kelas 1. Dalam hal ini prosentase tertinggi atau mayoritas TP di Situs Medowo memiliki kerapatan artefak dengan kategori kelas 1 (gambar 4, 5, 6, dan 7). 


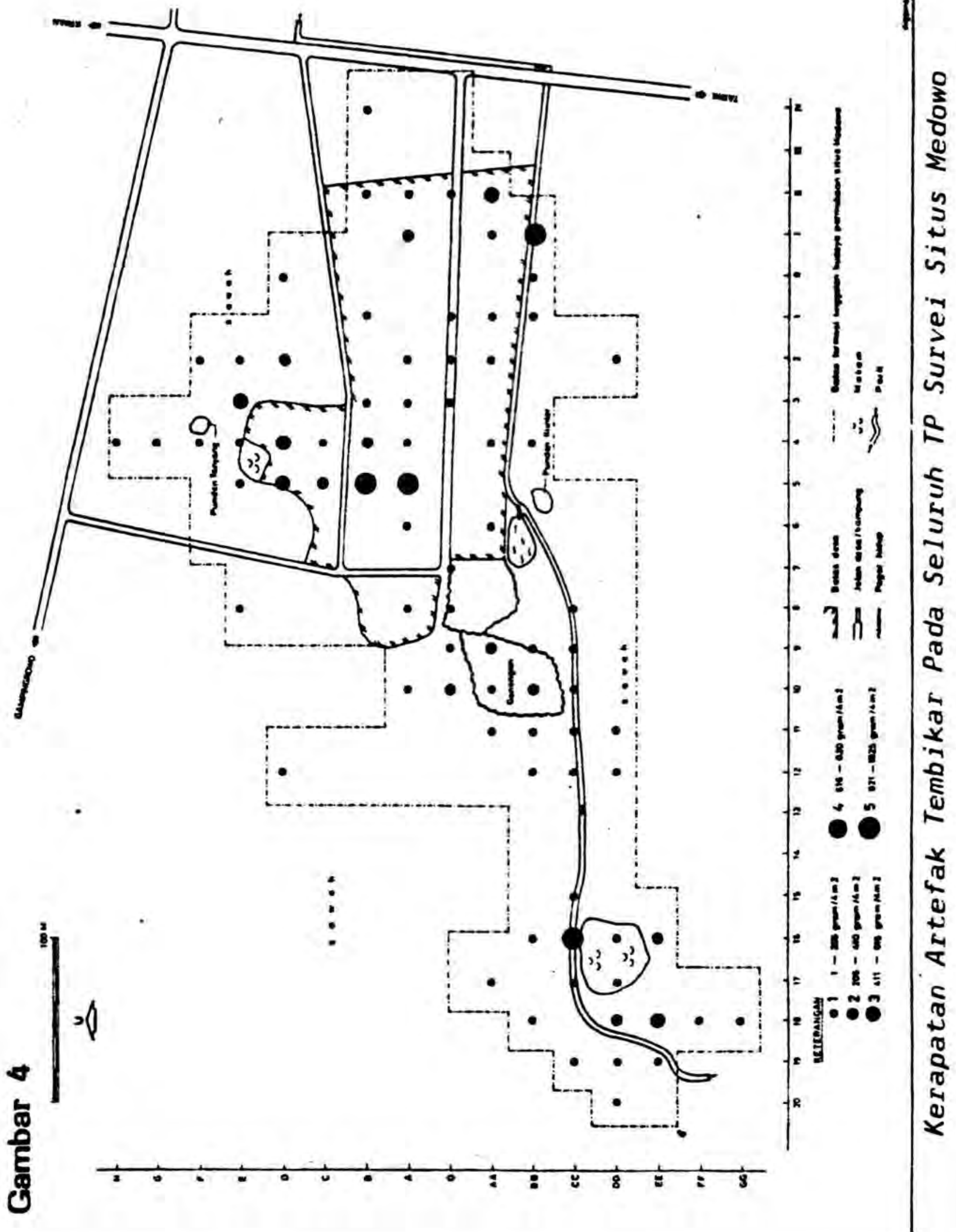




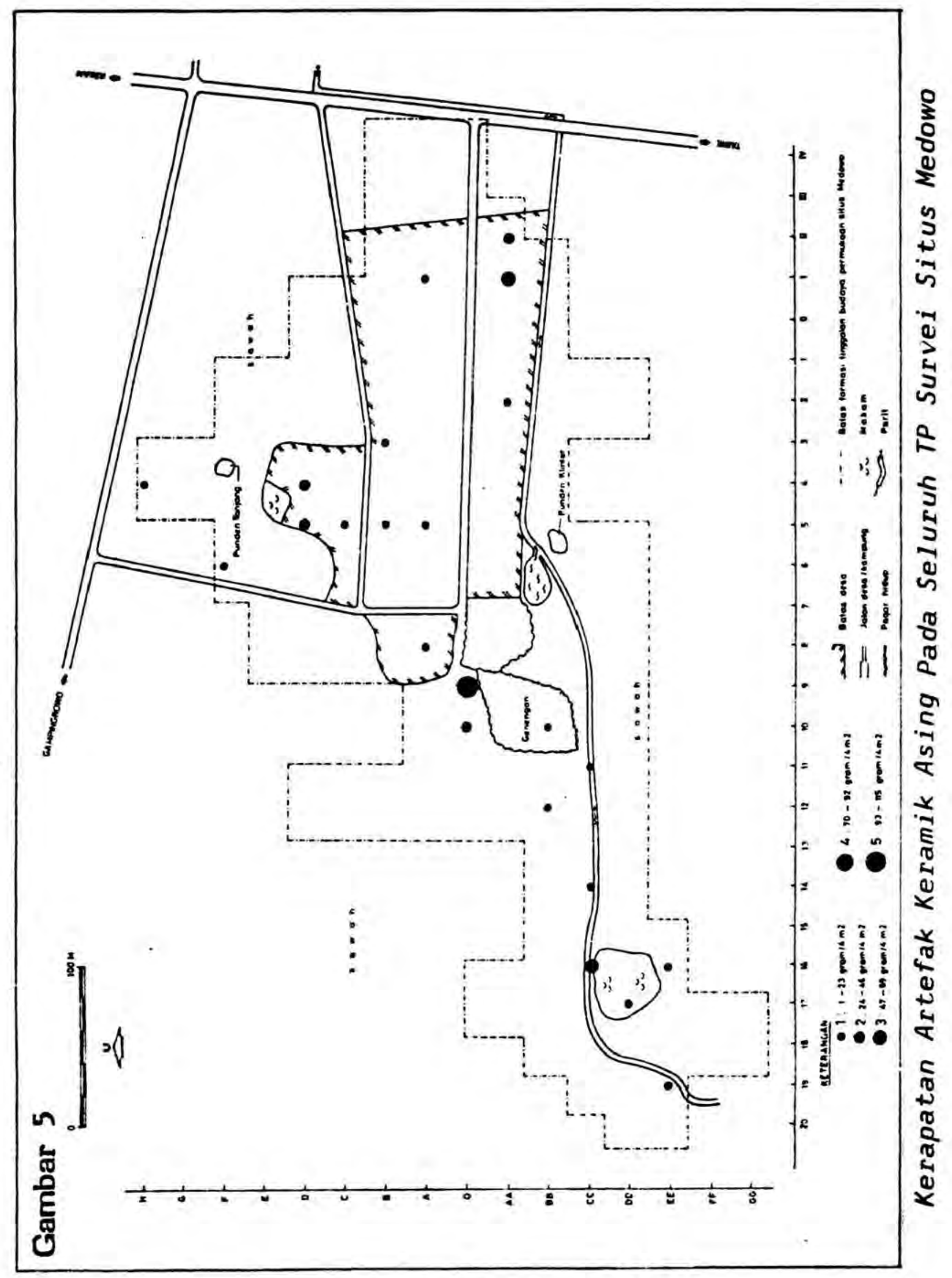




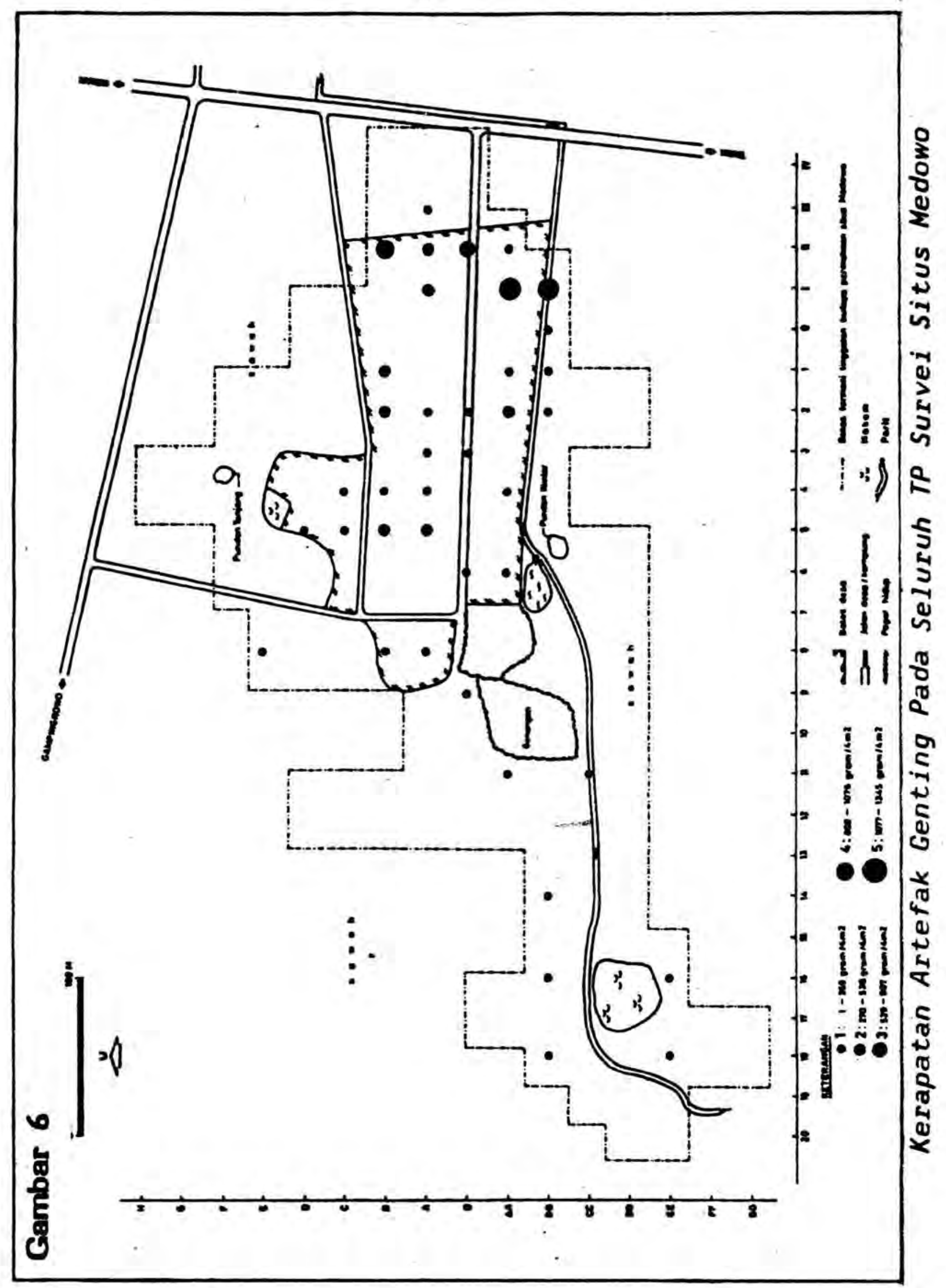




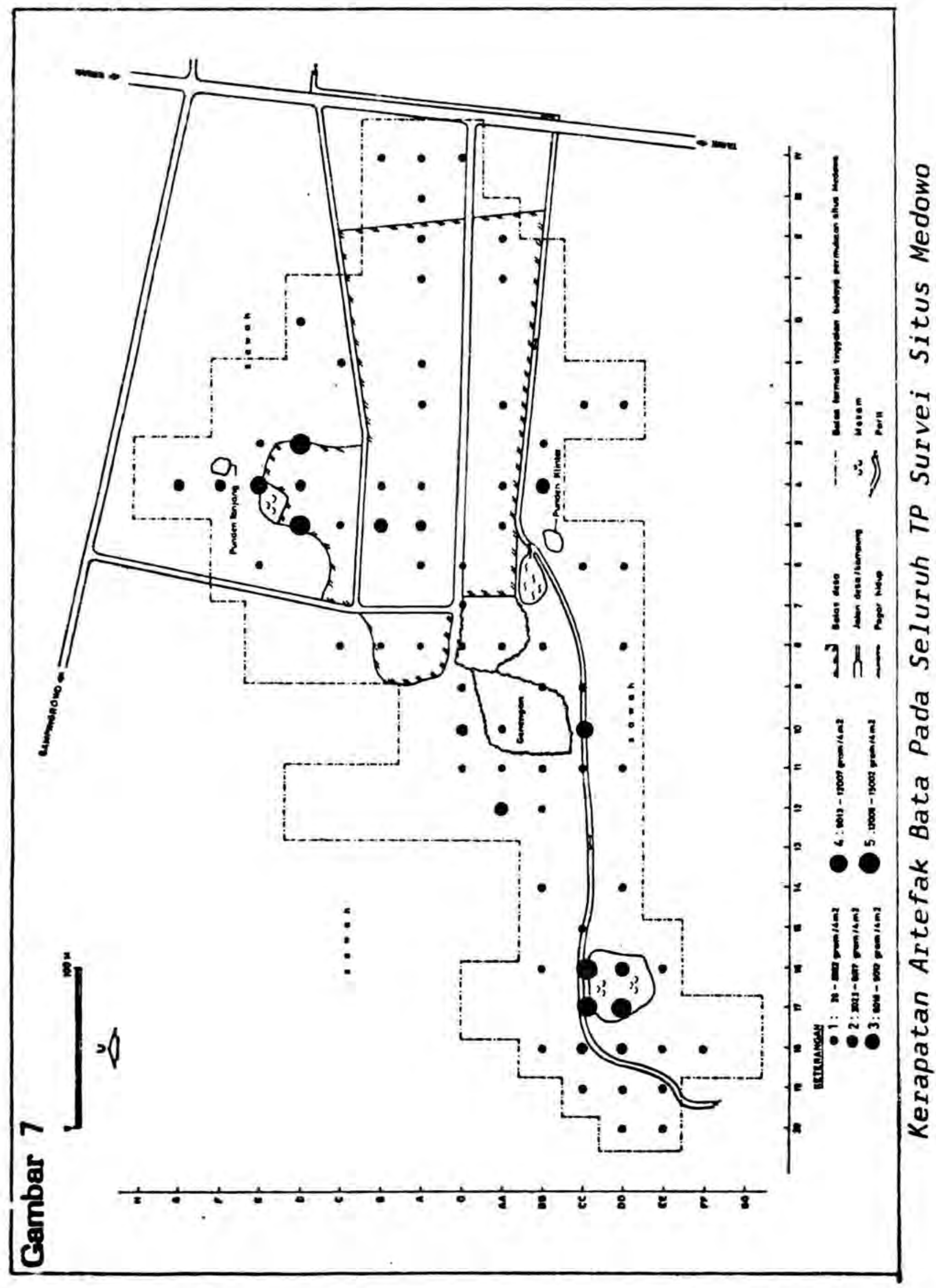




\section{Penutup}

Formasi tinggalan budaya bercorak Indonesia kuna di permukaan Situs Medowo tersebar pada areal seluas $28 \mathrm{Ha}$. Tinggalan arkeologik tersebut meliputi artefak, ekofak, dan fitur, yang sebagian besar tersisa dalam beniuk fragmentarik. Rincian dari tinggalan arkeologik tersebut adalah meliputi tembikar, keramik asing, genting, bata, terakota, lumpang batu, batu calon prasasti, bandul jala, mata uang, tulang, alat logam, dan alat batu. Kecuali artefak tembikar, keramik asing, genting, dan bata yang dijumpai relatif merata, tinggalan arkeologik lain hadir secara sporadis saja.

Areal formasi tinggalan budaya tersebut secara pokok meliputi tata guna lahan hunian dan pertanian. Aktivitas masa kini tersebut mempengaruhi keberadaan tinggalan arkeologik permukaan. Namun demikian berdasarkan analisis di atas, diketahui bahwa transformasi obyek-obyek arkeologik dari konteks budaya ke konteks arkeologik permukaan tidak berlangsung secara horizontal melainkan lebih merupakan transformasi vertikal (perhatikan Schiffer 1976: 27-34). Dengan dernikian secara keruangan tinggalan arkeologik permukaan dapat diasumsikan mewakili himpunan tinggalan di bawah tanah (perhatikan Flannery 1976: 51-2), baik pada areal yang sekarang dimanfaatkan bagi aktivitas hunian maupun pertanian.

Tinggalan arkeologik permukaan di Situs Medowo memperlihatkan adanya pemusatan kerapatan pada empat cluster, yaitu area sekitar Makam Klinter (cluster Klinter), area Genengan dan sekitarnya (cluster Genengan), area sekitar Langgar dan Makam Medowo (cluster Medowo Utara), dan area sekitar sudut tenggara Dusun Medowo (cluster Medowo Tenggara). Agihan tinggalan arkeologik di luar empat cluster tersebut relatif rendah kerapatannya. 
Secara umum jenis artefak yang tinggi kerapatannya pada cluster-cluster tersebut relatif bervariasi. Pada cluster Klinter dan Genengan, misalnya, temuan artefak permukaannya didominasi oleh jenis bata, tembikar, dan keramik asing. Sebaliknya, artefak di permukaan cluster Medowo Tenggara didominasi oleh jenis genting, tembikar, dan keramik asing. Sementara itu intensitas jenisjenis artefak tembikar, keramik asing, dan bata di permukaan cluster Medowo Utara relatif setara.

Secara sepintas dari hasil studi eksploratif di atas dapat diduga pola penempatan ruang yang pernah berkembang di Situs Medowo, terutama pada masing-masing cluster. Cluster Klinter dan Genengan memperlihatkan adanya pemusatan bangunan yang menggunakan bahan bata, namun sedikit memanfaatkan unsur genting. Sebaliknya cluster Medowo Tenggara memperlihatkan adanya pemusatan fasilitas bangunan yang menggunakan unsur genting, namun sedikit sekali memanfaatkan bata sebagai bahan bangunan. Sementara itu pemusatan bangunan di cluster Medowo Utara memperlihatkan kecenderungan penggunaan bata sebagai bahan bangunan sekaligus pemanfaatan genting sebagai atap.

\section{Penghargaan}

Ilustrasi peta, gambar, dan diagram pada tulisan ini dikerjakan oleh R. Adji Satrio dan Hadi Sunaryo. Untuk semua itu disampaikan penghargaan dan terima kasih. 


\section{KEPUSTAKAAN}

Clark, G.A. 1985. Quantifying Archaeological Research, dalam Michael B. Schiffer (peny.) Advances in Archaeological Method and Theory, Vol. 5. New York: Academic Press, Inc. Hlm. 217 73.

Mueller, James W. 1975. Archaeological Research as Cluster Sampling, dalam James W. Mueller (peny.) Sampling in Archaeology. Arizona : The University of Arizona Press. Hlm. $33-41$.

Flannery, Kent V. 1976. Sampling by Intensive Surface Collection, dalam Kent V.Flannery (peny.) The

Early Mesoamerican Village. New York: Academic Press, Inc. HIm. $51-62$.

Pasaribu, Amudi, 1965. Pengantar Statistik. Jakarta : Ghalia Indonesia.

Redman, Charles L. 1973. Multi stage Fieldwork. and Analytical Techniques, American Antiquity, 38. HIm. 61 - 79.

Redman, Charles L. 1974. Archaeological Sampling Strategies. An Addison-Wesley Module in Anthropology, 55. Addison-Wesley Publishing, Inc. HIm. 1 - 34.

Reid, J. Jefferson; Michael B. Schiffer; dan Jeffrey Neff. 1975. Archaeological Confiderations of Intrasite Sampling, dalam James W. Mueller (peny.) Sampling in Archaeology. Arizona: The Univ. of Arizona Press. HIm. 209-24.

Schiffer, Michael B. Behavioural Archaeology. New York: Academic Press, Inc. 